\title{
PENGARUH PROGRAM EVENT FAMILY GATHERING TERHADAP LOYALITAS PELANGGAN BISNIS PADA HOTEL NUANSA BALI ANYER
}

\author{
Ridwan Purnama \\ Fina Afiani
}

\begin{abstract}
Abstrak
Tingkat persaingan di bisnis jasa perhotelan semakin hari semakin kompetitif. Hal ini ditandai dengan semakin ekspansif dan bertambahnya jumlah hotel, baik dikawasan pariwisata maupun di kawasan bisnis. Di kawasan Anyer, terdapat beberapa hotel yang memiliki segmen sama, antara lain Hotel Nuansa Bali, Marbella, Mambruk, Jayakarta, dan Shangiang. Masalah yang dihadapi oleh Hotel Nuansa Bali adalah menurunnya tingkat loyalitas pelanggan bisnis yang biasa menggunakan jasa Hotel Nuansa Bali. Untuk mengatasi masalah tersebut, Hotel Nuansa Bali harus menemukan solusi yang tepat untuk mengalahkan pesaing setiap tahunnya. Salah satu strategi yang dilaksanakan oleh untuk meningkatkan kembali loyalitas pelanggan bisnis-nya ialah melalui program event family gathering. Tujuan penelitian ini ialah untuk memperoleh gambaran mengenai program event family gathering dan loyalitas pelanggan bisnis Hotel Nuansa Bali, serta untuk mengetahui sejauhmana pengaruh program event family gathering terhadap loyalitas pelanggan bisnis di Hotel Nuansa Bali.

Berdasarkan variabel yang diteliti, maka jenis penelitian ini adalah penelitian deskriptif dan verifikatif. Metode pengembangan penelitian bersifat cross sectional method. Populasi penelitian ini ialah pelanggan bisnis (perusahaan) yang mengikuti event family gathering pada tahun 2006, 2007, dan 2008 di Hotel Nuansa Bali Anyer yang berjumlah 20 perusahaan. Penelitian ini menggunakan sampling jenuh, sehingga sampel yang diteliti merupakan seluruh anggota populasi.

Hasil penelitian menunjukkan program event family gathering secara umum sudah dilaksanakan dengan baik, dimana indikator variasi event family gathering memperoleh skor tertinggi, sedangkan indikator manfaat nilai pesan melalui event family gathering memperoleh skor paling rendah. Loyalitas pelanggan secara umum termasuk kategori sudah baik, dimana penggunaan ulang program event family gathering merupakan indikator yang memperoleh skor paling tinggi, sedangkan persepsi responden merekomendasikan kepada orang lain mendapatkan skor yang paling rendah dibandingkan indikator lainnya. Program event family gathering berpengaruh secara positif terhadap loyalitas pelanggan. Sehingga program acara yang berkualitas, inovatif, dan berbeda dengan perusahaan lain akan memberikan pengaruh yang positif terhadap loyalitas pelanggan.
\end{abstract}

\section{Kata Kunci : Event Family Gathring dan Loyalitas Pelanggan}

\section{PENDAHULUAN}

Era globalisasi mengakibatkan persaingan bisnis semakin tinggi dan teknologi informasi serta komunikasi yang semakin canggih. Masyarakat di seluruh dunia akan saling berhubungan untuk mencari informasi satu sama lain khususnya dalam bidang bisnis tanpa ada hambatan. Masyarakat dapat mengakses informasi kapanpun sesuai dengan keinginannya. Persaingan bisnis tidak hanya berlangsung antar bangsa tetapi sudah mengglobal. Hal ini diakibatkan karena sudah semakin maju teknologi dan informasi di dunia.

Di Kawasan Asia Pasifik, proses globalisasi akan mencapai puncaknya pada tahun 2020 dengan pemberlakuan APEC. Pada saat ini, kawasan Asia Tenggara Tengah memasuki persaingan bebas dengan pemberlakuan AFTA (Asean Free Trade Area).

Intensitas persaingan bisnis yang meningkat dewasa ini memacu dunia usaha lebih peduli terhadap strategi yang membawanya kepada dua hal yaitu keunggulan dan nilai. Keunggulan dapat berupa keunggulan menginduk (parenting adventage) untuk korporasi dan keunggulan bersaing (competitive adventage) untuk bisnis.

Perusahaan-perusahaan jasa keuangan, agen periklanan hotel dan pariwisata, restoran cepat saji, bahkan rumah sakit saat ini telah beroperasi di beberapa dunia. Strategi perluasan bisnis dengan cara ini mencerminkan keinginan untuk melayani konsumen yang ada maupun upaya untuk melakukan penetrasi ke pasar baru. 


\section{StrategiC}

Pariwisata merupakan perwujudan komunikasi antar bangsa, pariwisata tidak akan dapat berjalan dengan baik bila tidak didukung komunikasi yang lancar. Kedua hal ini saling terkait dengan erat. Oleh karena itu pariwisata termasuk perhotelan, sangat menekankan pentingnya pemakaian manajemen komunikasi dan pengelolaan sistem informasi secara maksimal agar dapat melaksanakan misi pelayanan dengan sebaikbaiknya.

Prasarana pariwisata adalah semua fasilitas utama atau dasar yang memungkinkan sarana kepariwisataan dapat hidup dan berkembang dalam rangka memberikan pelayanan kepada wisatawan. Sarana pariwisata adalah fasilitas dan perusahaan yang memberikan pelayanan kepada wisatawan baik secara langsung maupun tidak langsung. Maju mundurnya sarana kepariwisataan tergantung pada jumlah kunjungan wisatawan. Oleh karena itu keberadaan sarana pariwisata sangatlah penting dan mutlak untuk menyajikan pelayanan yang berkualitas kepada para wisatawan. Salah satu komponen penting dalam kegiatan pariwisata adalah aksesibilitas atau kelancaran perpindahan seseorang dari satu tempat ke tempat lainnya.

Pada tahun 1998 kepariwisataan Indonesia relatif menurun disebabkan oleh pergantian kekuasaan dari Orde Baru ke Orde Reformasi yang menimbulkan kerusuhan hampir di seluruh kota besar di Indonesia. Berbagai kejadiaan yang menimpa kepariwisataan Indonesia seperti tragedi bom Bali pada tahun 2002, bom di Hotel JW Marriott pada tahun 2003 dan lain-lain tidak mengurangi perhatian pemerintah di sektor pariwisata. Kejadian-kejadian tersebut menjadi sebuah fenomena baru yang perfomanya diharapkan meningkat terus. Pariwisata-pariwisata tersebut sudah tentu membawa kepedihan, tetapi tidak berdampak besar terhadap perekonomian negara. Hal ini didukung oleh sikap profesional dan proaktif pemerintah Indonesia dalam menangani krisis keamanan yang menimbulkan simpati dan dukungan dari negara-negara dunia.

Saat ini pariwisata Indonesia masih dihadapkan pada persoalan mendasar yakni memulihkan kepercayaan wisatawan untuk datang ke Indonesia. Untuk memulihkan kepercayaan wisatawan pasca-musibah yang disebabkan oleh perubahan iklim global tentunya perlu kerja keras semua pihak baik pemerintah, perilaku bisnis, maupun masyarakat (pers) dengan melakukan berbagai langkah strategis. Munculnya berbagai peristiwa dan musibah selama tahun 2005, 2006, 2007 sampai saat ini merugikan pariwisata, cukup besar pengaruhnya terhadap kunjungan wisatawan lokal maupun wisatawan mancanegara (wisman) ke Indonesia.

Industri pariwisata cukup banyak di Indonesia, salah satunya industri pariwisata di Propinsi Banten. Berdirinya Propinsi Banten pada tahun 2002 telah banyak menarik perhatian wisatawan nusantara dan wisatawan mancanegara dalam sektor pariwisata.

Data mengenai jumlah wisatawan tahun 2007 dibeberapa kaabupaten dan kota di Propinsi Banten dapat diperlihatkan dalam bentuk Tabel 1.

Tabel 1

Jumlah Wisatawan Tahun 2007

\begin{tabular}{|l|r||r|r|}
\hline \multirow{2}{*}{ Kab / Kota } & \multicolumn{1}{|c|}{ Kunjungan Wisatawan } & \multicolumn{1}{c|}{ Total } \\
\cline { 2 - 3 } & \multicolumn{1}{c|}{ Wisnus } & Wisman & \multicolumn{1}{c|}{} \\
\hline Kab. Serang & $6,439,789$ & 1,286 & $\mathbf{6 , 4 4 1 , 0 7 5}$ \\
\hline Kab. Pandeglang & 365,889 & 1,737 & $\mathbf{3 6 7 , 6 2 6}$ \\
\hline Kab. Lebak & 17,761 & 36 & $\mathbf{1 7 , 7 9 7}$ \\
\hline Kab. Tangerang & $11,610,000$ & 13,950 & $11,623,950$ \\
\hline Kota Cilegon & 106,366 & 5,419 & 111,785 \\
\hline Kota Tangerang & 180,377 & 76,789 & $\mathbf{2 5 7 , 1 6 6}$ \\
\hline JUMLAH & $\mathbf{1 8 , 7 2 0 , 1 8 2}$ & $\mathbf{9 9 , 2 1 7}$ & $\mathbf{1 8 , 8 1 9 , 3 9 9}$ \\
\hline
\end{tabular}

Sumber: Pemerintah Kab/Kota se-Provinsi Banten (2008)

Berdasarkan Tabel 1 diatas dapat kita lihat wisatawan nusantara di kabupaten Serang sebesar $34,4 \%$, dan wisatawan mancanegara sebesar $1,3 \%$, wisatawan nusantara di kabupaten pandeglang sebesar $1.96 \%$ dan wisatawan mancanegara $1,75 \%$, di kabupaten Lebak wisatawan nusantara sebesar $0,09 \%$ dan wisatawan mancanegara $0,04 \%$, wisatawan nusantara di kabupaten Tanggerang sebesar $62,02 \%$ dan wisatawan mancanegara sebesar $14,06 \%$, di kota Cilegon wisatawan nusantara sebesar $0,57 \%$ dan wisatawan mancanegara sebesar $5,46 \%$, dan di kota Tanggerang sebesar $0,96 \%$ wisatawan nusantara dan $77,4 \%$ wisatawan mancanegara.

Total terbesar kunjungan wisatawan nusantara dan wisatawan mancanegara yaitu kabupaten Tanggerang, karena sebelum Banten menjadi sebuah Propinsi, kabupaten Tanggerang telah menjadi suatu daerah yang maju. Hal ini terlihat dari beberapa fasilitas umum yang sangat menunjang bagi masyarakat di kabupaten tanggerang. 
Salah satu hal yang menunjang dalam industri pariwisata yaitu perhotelan. Hotel adalah suatu perusahaan yang dikelola oleh pemiliknya dengan menyediakan pelayanan makanan, minuman dan fasilitas kamar untuk tidur kepada orang-orang yang sedang melakukan perjalanan dan mampu membayar dengan pelayanan yang diterima tanpa adanya perjanjian khusus.

Bidang perhotelan sebenarnya telah berkembang menjadi satu industri besar. Tingginya persaingan pada dunia bisnis hampir terjadi pada seluruh industri dan jasa termasuk di dalamnya industri hotel, para produsen dalam indusrti ini dituntut untuk melakukan terobosan bisnis yang baru agar dapat mengungguli para pesaingnya dan harus senantiasa selalu melakukan pengembangan terhadap produk-produknya secara optimal, serta mengetahui apa yang dibutuhkan oleh pelanggan, sehingga kepuasan pelanggan selalu terjaga dan pelanggan tidak akan merasa bosan.

Berdasarkan data pertumbuhan market size beberapa sektor industri yang di dalamnya termasuk industri perhotelan dari tahun 2005 sampai tahun 2007 (Majalah Danareksa Research Institute-SWA 01/XXIII/4-17 januari 2007), dapat dilihat bahwa pangsa pasar industri perhotelan mengalami perubahan yang fluktuatif dari tahun 2005 sampai tahun 2007. Di tahun 2005 memperoleh pangsa pasar $6,7 \%$, tahun 2006 sebesar 2,7\% dan pada tahun 2007 pangsa pasar industri perhotelan mengalami kenaikan yaitu menjadi $7,3 \%$. Berdasarkan hal ini memperlihatkan bahwa industri ini perlu diperhatikan oleh perusahaan yang bergerak dalam industri perhotelan untuk dapat mempertahankan dan meningkatkan pangsa pasarnya.

Industri perhotelan di Propinsi Banten terlihat cukup banyak dan maju. Hal tersebut berdasarkan data tingkat okupansi kamar hotel di beberapa Kabupaten dan Kota di Propinsi Banten tahun 2001-2005 (Dinas Kebudayaan \& Pariwisata Banten, 2008). Dapat dilihat bahwa tingkat okupansi kamar hotel di Kabupaten Pandeglang dari tahun 2001-2005 sebesar 134,62, dan Kabupaten Lebak sebesar 218,43 dari tahun 20012005, dan sebesar 257,41 di Kabupaten Tanggerang, Kabupaten Serang sebesar 322,91 dari tahun 2001-2005, dan Kota Tanggerang sebesar 298,17, sedangkan Kota Cilegon sebesar 199.36 dari tahun 2001-2005, dapat dilihat bahwa tingkat tertinggi okupansi kamar hotel tahun 20012005 yaitu Kabupaten Serang, sedangkan untuk tingkat terendah okupansi kamar hotel tahun 20012005 yaitu Kabupaten Pandeglang. Apabila dilihat dari tahun ke tahunnya tingkat okupansi kamar hotel tertinggi yaitu pada tahun 2005 sebesar 59,76 , dan terendah yaitu pada tahun 2001 sebesar 34,30. Dapat diketahui bahwa data tingkat okupansi kamar hotel dari tahun ke tahun mengalami kenaikan dari tahun 2001 sebesar 34,30, tahun 2002 sebesar 38,39, tahun 2003 sebesar 53,73, tahun 2004 sebesar 58,64, dan pada tahun 2005 sebesar 59,76.

Propinsi Banten sebagai salah satu daerah tujuan wisata di Indonesia terus berupaya meningkatkan industri pariwisata sebagai salah satu sumber pendapatan daerah. Peningkatan jumlah wisatawan nusantara maupun mancanegara memberikan peningkatan terhadap permintaan akan kamar hotel sebagai tempat untuk menginap atau beristirahat. Untuk mengetahui jumlah akomodasi wisata di Propinsi Banten tahun 2001-2005 berikut dapat diperlihatkan dalam bentuk Tabel 2.

Tabel 2

Jumlah Akomodasi Wisata di Propinsi Banten Tahun 2001-2005

\begin{tabular}{|c|c|c|c|c|}
\hline \multirow{2}{*}{ Tahun } & \multicolumn{4}{|c|}{ Jenis Akomodasi } \\
\cline { 2 - 5 } & $\begin{array}{c}\text { Hotel } \\
\text { Berbintang }\end{array}$ & $\begin{array}{c}\text { Hotel } \\
\text { Non Berbintang }\end{array}$ & Restoran & $\begin{array}{c}\text { Rumah } \\
\text { Makan }\end{array}$ \\
\hline 2001 & 35 & 115 & 216 & 404 \\
\hline 2002 & 35 & 115 & 152 & 337 \\
\hline 2003 & 27 & 122 & 146 & 358 \\
\hline 2004 & 27 & 114 & 138 & 332 \\
\hline 2005 & 27 & 108 & 119 & 296 \\
\hline
\end{tabular}

Sumber : Dinas kebudayaan \& pariwisata Banten, 2008

Berdasarkan Tabel 2 di atas dapat kita lihat hotel berbintang pada tahun 2002 mengalami penurunan sebesar 22,85\%, 2003 - 2005 mengalami kestabilan. Hotel non bintang pada tahun 2002 ssebesar 0\%, 2003 mengalami penurunan sebesar $6,09 \%, 2004$ juga mengalami penurunan sebesar $6,96 \%$ dan di 2005 mengalami penurunan sebesar $5,21 \%$. Untuk restaurant, di tahun 2002 mengalami penurunan sebesar $0,3 \%$, 2003 mengalami penurunan sebesar 0,04\%, 2004 mengalami penurunan sebesar $0,05 \%$ dan 2005 mengalami penurunan sebesar $0,14 \%$. Dilihat dari Rumah Makan mengalami penurunan dari tahun 2002 sampai dengan 2005 secara berturut-turut sebesar, $0,16 \%, 0,06 \%, 0,07 \%$, dan $0,11 \%$. 
Penurunan ini disebabkan karena adanya isyu tentang Tsunami tehadap daerah pariwisata pesisir pantai. Hal ini membuka peluang bagi pariwisata daerah selain pesisir pantai, misalnya puncak dan sekitarnya.

Pengembangan kepariwisataan di Propinsi Banten saat ini semakin penting, tidak saja dalam rangka meningkatkan penerimaan devisa negara, akan tetapi juga dalam rangka memperluas kesempatan kerja dan pemerataan pendapatan daerah. Peningkatan jumlah wisatawan nusantara maupun mancanegara memberikan peningkatan pula terhadap permintaan akan kamar hotel sebagai tempat untuk menginap atau beristirahat. Untuk mengetahui industri persaingan hotel yang terdapat di wilayah atau Kabupaten/Kota Propinsi Banten dari tahun 2002-2006 terdapat jumlah hotel berbintang dan non bintang yang dapat kita lihat pada Gambar 1 di bawah ini.

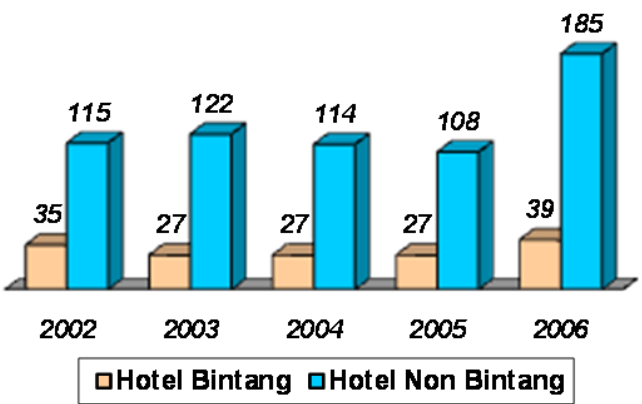

Sumber: Dinas Kebudayaan dan Pariwisata Banten (2008)

$$
\begin{gathered}
\text { Gambar } 1 \\
\text { Jumlah Hotel Bintang dan Non Bintang (Buah) } \\
\text { Tahun 2002 - } 2006
\end{gathered}
$$

Gambar 1 menunjukan bahwa hotel non bintang dari tahun 2002-2006 mengalami kenaikan yang cukup pesat dibandingkan dengan hotel bintang memiliki jumlah yang cukup jauh, tetapi dilihat dari tahun 2002-2005 hotel bintangpun selalu mengalami penurunan,tetapi di tahun 2006 mengalami kenaikan.

Meningkatnya pariwisata di Propinsi Banten yang dikunjungi oleh beberapa tamu nusantara dan tamu mancanegara pada hotel (orang) dari tahun ke tahun mengalami penurunan dan kenaikan. Berikut ini akan diperlihatkann dalam bentuk

Gambar 2 data mengenai jumlah tamu nusantara dan tamu mancanegara pada hotel (orang) dari tahun 2002-2005.

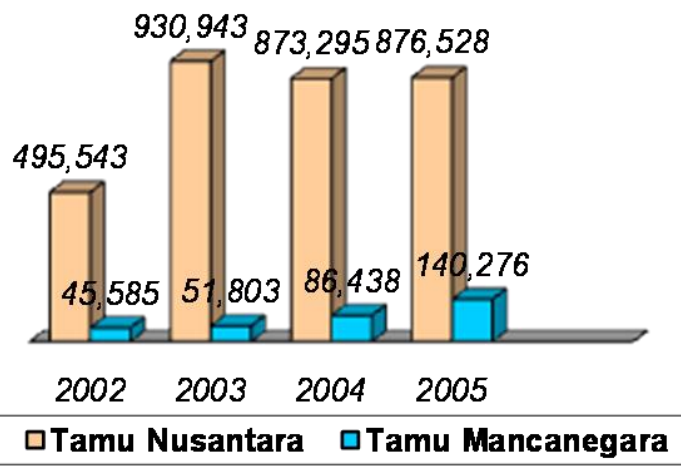

Sumber: Dinas Kebudayaan dan Pariwisata Banten (2008)

Gambar 2

Jumlah Tamu Nusantara dan Tamu Mancanegara Pada Hotel (Orang) Tahun 2002-2005

Gambar 2 di atas dapat kita lihat bahwa tamu nusantara pada tahun 2002 sebesar 495,543 dan mengalami kenaikan pada tahun 2003 sebesar 930,943 dan mengalami penurunan yang cukup drastis pada tahun 2004 sebesar 873,295 dan mengalami sedikit penurunan dari tahun 20042005. Dilihat dari tamu mancanegara dari tahun ke tahun mengalami kenaikan yang cukup besar apalagi dilihat pada tahun 2005 sebesar140,276.

Daerah tujuan wisata utama di Banten adalah Anyer. Anyer menjadi tempat tujuan wisata utama terkenal dengan pantainya yang berpasir putih dan adanya sejumlah tempat rekreasi seperti wisata air, surfing, diving, fishing, dan lain-lain. Selain itu juga terdapat beberapa hotel di Anyer untuk para pengunjungnya yang ingin menginap di daerah wisata Anyer tersebut, diantaranya yaitu Hotel Marbella, Jayakarta, Shangiang, Mambruk, dan Nuansa Bali. Setiap hotel mempunyai strateginya masing-masing untuk menarik para konsumennya.

Banyaknya pengunjung wisatawan yang berkunjung ke wilayah Anyer Banten untuk berwisata maka semakin banyaknya hotel-hotel yang terdapat di wilayah Anyer dan semakin banyak pula pesaing-pesaing hotel di wilayah tersebut. Begitupun dengan jumlah penggunaan kamar yang terjadi di tahun 2007 dan 2008 dari beberapa hotel di anyer, beberapa pesaingnya seperti yang terdapat dalam Tabel 3 Hotel Competitors di bawah ini. 
Tabel 3

Jumlah Pemakaian Kamar

Competitors Tahun 2007 dan 2008

\begin{tabular}{|l|c|c|}
\hline \multicolumn{1}{|c|}{ Nama Hotel } & $\begin{array}{c}\text { Jum. Pemakaian } \\
\text { Kamar 2007 }\end{array}$ & $\begin{array}{c}\text { Jum. Pemakaian } \\
\text { kamar 2008 }\end{array}$ \\
\hline Nuansa Bali & 5363 & 4986 \\
\hline Shangiang & 3062 & 3115 \\
\hline Mambruk & 10626 & 15019 \\
\hline Marbella & 26076 & 26809 \\
\hline Jayakarta & 4365 & 4125 \\
\hline
\end{tabular}

Sumber: Customer Service Hotel Nuansa Bali, 2008

Tabel 3 menunjukan bahwa pada tahun 2007 pesaing yang unggul yaitu Marbella sebesar 26076 ,sedangkan Nuansa Bali berada di posisi tengah sebesar 5363 di tahun 2007 dan di tahun 2008 sebesar 4986, jumlah yang dilihat dari jumlah pemakaian kamar, Hotel Nuansa Bali di bawah Hotel Marbella dan Hotel Mambruk, sedangkan tahun 2008 masih unggul Marbella yang memiliki jumlah yang terbesar yaitu sebesar 28079, dan Jayakarta sebesar 4156, dan Nuansa Bali sebesar 4986 sedangkan Shangiang adalah sebesar 3115.

Hal ini merupakan salah satu dampak dari menurunnya kepercayaan wisatawan terhadap pariwisata yang disebabkan oleh perubahan iklim global yang akhir-akhir ini selalu disertai dengan bencana alam. Ternyata adanya perubahan iklim global menuntut perusahaan-perusahaan perhotelan agar semakin berusaha meningkatkan daya tariknya untuk menarik sejumlah pelanggan dalam jumlah yang banyak atau pun untuk mendapatkan pelanggan yang loyal. Salah satu hotel yang mengalami penurunan adalah Hotel Nuansa Bali, yang dapat dilihat pada Tabel $1.3 \mathrm{di}$ atas. Masalah yang terdapat di Hotel Nuansa Bali yaitu agar bisa mengalahkan pesaing-pesaing hotel yang terdapat di wilayah Anyer agar dapat setara atau seimbang dengan pesaing yang ada. Pada intinya pihak perhotelan harus mampu menentukan strategi yang efektif, terutama dalam mengkomunikasikan manfaat dan daya guna jasa perhotelan melalui kiat membujuk (persuasive) dan slogan atau kata-kata yang menarik (magic world), sesuai dengan orientasi kebutuhan pelanggan.

Segmentasi dari Hotel Nuansa Bali yaitu keluarga, anak-anak sekolah, Mahasiswa, dan organisasi-organisasi atau perusahaanperusahaan, karena karakteristik konsumen tersebut cenderung hidup dalam suatu kelompok yang sudah pasti cenderung melakukan suatu kegiatan dengan cara berkelompok pula. Seperti contohnya suatu perusahaan ataupun mahasiswa mengadakan suatu seminar dan atau kunjungan wisata sehingga banyak memerlukan banyak kamar, bungalow, cottage, ataupun meeting room. Adapun jumlah pengunjung Hotel Nuansa Bali periode tahun 2006 sampai tahun 2008 adalah sebagai berikut.

Tabel 4

Jumlah Pengunjung Hotel Nuansa Bali Periode Tahun 2006-2008

\begin{tabular}{|c|c|c|}
\hline \multicolumn{3}{|c|}{ Tahun } \\
\hline 2006 & 2007 & 2008 \\
\hline 9827 & 12635 & 12339 \\
\hline
\end{tabular}

Sumber: Customer Service Hotel Nuansa Bali, 2008

Berdasarkan dari Tabel 1.4 dapat kita lihat bahwa pengunjung Hotel Nuansa Bali periode 2006-2008 mengalami kenaikan dan penurunan sebesar 9827 pada tahun 2006, pada tahun 2007 sebesar 12635 , dan terus mengalami penurunan pada tahun 2008 sebesar 12339. Di duga fenomena penurunan pengunjung Hotel Nuansa Bali di sebabkan karena kualitas pelayanan yang diberikan Hotel Nuansa Bali kurang memuaskan pengunjung serta fasilitas yang tedapat di Hotel Nuansa Bali kurang lengkap, diantaranya fasilitas yang tersedia adalah seperti meeting room, swimming pool, convention centre, water sport, Al Fresco restaurant, discotique, coffe shop, green house cafe, dan fitness centre. Untuk mempertahankan dan meningkatkan pengunjung pihak hotel berupaya lebih meningkatkan kualitas pelayanan dan lebih melengkapi fasilitas, serta menanggapi dan memperbaiki keluhan atau saransaran yang didapat dari para pengunjung. Selain memperbaiki keluhan atau saran-saran yang didapat dari pengunjung Hotel Nuansa Bali juga melakukan pendekatan melalui event-event yang dilakukan di Hotel Nuansa Bali salah satunya adalah melakukan event family gathering.

Sejalan dengan melemahnya periklanan massal dikarenakan biayanya yang terlalu besar dan sudah terlalu umum digunakan oleh berbagai perusahaan untuk berpromosi, maka semakin banyak perusahaan terutama perusahaan perhotelan yang berpaling untuk membuat event yang menarik, alasannya mereka menganggap bahwa event efektif terutama dalam membangun kesadaran dan pengetahuan merek. Selain itupun 
mampu mempengaruhi kesadaran publik dengan biaya yang lebih kecil daripada iklan, dan seringkali lebih dipercaya.

Sejauh ini event dapat membantu perusahaan untuk menarik pelanggan, adapun tujuan event, yaitu untuk mengidentifikasi sebuah pasar sasaran khusus atau gaya hidup, untuk meningkatkan kesadaran nama perusahaan atau produk, untuk menciptakan atau mengukuhkan persepsi konsumen tentang asosiasi citra merek, Untuk meningkatkan dimensi citra perusahaan, untuk menciptakan pengalaman dan membangkitkan perasaan, untuk mengungkapkan komitmen pada komunitas atau pada isu sosial, untuk menghibur klien utama atau mengimbali karyawan kunci, untuk memungkinkan peluang perdagangan atau promosi. Event perlu diterapkan secara sungguhsungguh oleh pihak perhotelan agar mampu memperkuat keunggulan kompetitif dan diharapkan mampu meningkatkan tingkat loyalitas pelanggan.

Berdasarkan situasi yang terjadi saat ini dengan melihat status para pesaingnya yang merupakan hotel-hotel berbintang yang tentunya telah mampu melekatkan image-nya di mata konsumen seperti Marbella Hotel, dan Jayakarta Hotel, maka Hotel Nuansa Bali mencoba menetapkan event sebagai strategi pemasarannya selain dari periklanan.

Salah satu kegitan event yang dilakukan Hotel Nuansa Bali adalah untuk mempertahankan kenaikan pengunjungnya dan agar dapat setara atau seimbang dengan pesaing yang ada yaitu dengan melakukan event, diantaranya menjadi event tempat pemilihan Putri Indonesia Regional Banten tahun 2005, menyelenggarakan acaraacara live musik mingguan, dan acara perayaan malam pergantian tahun dan event yang paling sering dilakukan di Hotel Nuansa Bali yaitu event family gathering. Family gathering adalah salah satu cara atau strategi yang dilakukan oleh praktisi public relation dalam suatu perusahaan untuk meningkatkan kinerja karyawannya yang melibatkan tidak hanya karyawannya saja tetapi juga mengikut sertakan keluarga mereka, atau acara yang bersumber dari kebijakan suatu perusahaan yang dilakukan secara rutinitas yang dilakukan oleh perusahaan, dimana yang setiap bulannya selalu dilakukan oleh pihak Hotel Nuansa Bali untuk perusahaan-perusahaan yang sudah loyal kepada Hotel Nuansa Bali.
Berdasarkan latar belakang penelitian di atas, maka penulis menjabarkan rumusan masalah penelitian sebagai berikut:

1. Bagaimana gambaran program event family gathering yang dilakukan Hotel Nuansa Bali

2. Bagaimana gambaran loyalitas pelanggan Hotel Nuansa Bali.

3. Seberapa besar pengaruh program event family gathering terhadap loyalitas pelanggan Hotel Nuansa Bali.

\section{KERANGKA PEMIKIRAN}

Persaingan antara perusahaan membuat pelaku bisnis untuk selalu berusaha menciptakan keunggulan kompetitif dari produk yang dipasarkannya. Keunggulan kompetitif dapat diciptakan dengan cara melakukan kegiatan marketing mix, sehingga produk barang atau jasa yang dipasarkan sesuai dengan keinginan dan kebutuhan konsumen di pasar.

Menurut Philip Kotler dan Keller (2006:17) yang dimaksud dengan marketing mix adalah "seperangkat alat pemasaran yang digunakan perusahaan untuk terus menerus mencapai tujuan pemasarannya di pasar sasaran".

Menurut Mc Charthy dalam Philip Kotler (2005:17) kegiatan marketing mix untuk produk barang terdiri dari empat komponen yaitu produk (Product), harga (Price), distribusi (Place), promosi (Promotion) atau yang lebih dikenal dengan istilah 4P yang menggambarkan pandangan penjual tentang alat-alat pemasaran yang dapat digunakan untuk mempengaruhi pembeli. Sejumlah penelitian menunjukkan bahwa 4P terlampau sempit untuk bisnis jasa. Hal ini mendorong banyak pakar pemasaran untuk mendefinisikan ulang bauran pemasaran sehingga lebih aplikatif untuk sektor jasa. Oleh karena itu 4P diperluas dan ditambah dengan unsur lainnya yaitu people, process, physical evidence, dan customer service (Fandy Tjiptono, 2005:31).

Menurut Kotler dan Keller (2006:205) promosi atau bauran komunikasi pemasaran terdiri dari enam cara utama, yaitu advertising, sales promotion, public relation,event and experience, personal selling, dan direct selling. Pada uraian diatas selanjutnya penulis hanya membahas bauran event dengan menggunakan strategi program event family gathering karena hal tersebut merupakan kegiatan event utama yang dilakukan oleh hotel Nuansa Bali. 
Event adalah kegiatan yang khusus diadakan oleh perusahaan yang dapat menarik perhatian pasar. Leonard $\mathrm{H}$. Hoyle dalam buku event marketing (2006:182)mendefinisikan Event merupakan tonggak posisi perusahaan untuk menjadi perusahaan yang berorientasi kemasyarakatan, yang berperan membantu masyarakat dalam mengelola masalah-masalah yang umum terjadi.

Terdapat beberapa komponen dalam hubungan masyarakat dalam pemasaran (marketing public relations) yang menurut Kotler, Bowen, and Makens yang dikutip oleh Vanessa Gaffar (2007:55) adalah publikasi, events berita, kegiatan sosial serta media identitas. Kualitas dari hubungan ini akan berdampak terhadap berita dan cerita perusahaan yang akan membentuk opini publik.

Acara-acara khusus yang diadakan oleh perusahaan dapat menarik perhatian pasar. Menurut Vanessa Gaffar (2007:56) acara khusus tersebut dibagi menjadi product event yaitu event yang berorientasi produk dengan tujuan untuk meningkatkan penjualan serta corporate event yaitu suatu event yang dirancang dan diselenggarakan perusahaan dengn nuansa hiburan yang diliputi oleh media lokal sehingga akan membangkitkan kesadaran, goodwill, dan minat. yang termasuk ke dalam acara khusus ini adalah konferensi, seminar, outings, eksibisi, kontes dan kompetisi, perayaan tahunan dan sponsorship terhadap acara budaya dan olahraga yang akan menjangkau publik sasaran.

Outing merupakan salah satu bagian dari event family gathering, dimana Menurut Bartono dan Ruffino (Hotel Communication Management; 2007: 107), Family Gathering merupakan pendekatan hotel pada hubungan primer dengan travel agent dan pemasok, juga mendekatkan hotel dalam hubungan sekunder dengan birokrasi pemerintahan yang berkaitan dengan saluran birokrasi pemerintah yang dapat menguntungkan hotel secara teknis, bisnis dan sosial lingkungan yang tidak hanya melibatkan karyawannya saja tetapi mengikut sertakan keluarganya.

Loyalitas pelanggan bisa memberikan dampak pertumbuhan pendaptan dan profitabilitas bagi perusahaan. Loyalitas pelanggan memiliki peran penting dalam sebuah organisasi perusahaan. Loyalitas pelanggan memiliki peran penting dalam sebuah organisasi perusahaan. Kotler (2005:84) mengemukakan pentingnya mempertahankan pelanggan yang loyal karena pelanggan yang loyal akan memberikan beberapa keuntungan bagi perusahaan antara lain pelanggan yang sangat puas akan tetap setia dalam waktu yang lebih lama, membeli lebih banyak ketika perusahaan memperkenalkan produk baru dan memperbaharui produk-produk yang sudah ada, membicarakan hal-hal yang baik tentang perusahaan dan produknya, memberikan perhatian yang lebih sedikit kepada para pesaing serta kurang peka terhadap harga, menawarkan gagasan tentang jasa atau produk kepada perusahaan, dan menumbuhkan biaya pelayanan yang lebih kecil dibandingkan biaya pelayanan pelanggan baru karena transaksinya rutin. Griffin (2002:4) yang menyatakan bahwa "Loyalty is defined as non random purchase expressed over time by some decision making unit."

Berdasarkan definisi tersebut dapat dijelaskan bahwa loyalitas lebih mengacu pada wujud perilaku dan unit-unit pengambilan keputusan untuk melakukan pembelian secara terus menerus terhadap barang atau jasa suatu perusahaan yang dipilih.

Menurut Griffin (2005:31), pelanggan yang loyal memiliki karakteristik sebagai berikut:

1. Makes regular repeat purchased. Pelanggan membeli produk atau jasa secara teratur

2. Purchase across product line and service. Pelanggan secara teratur membeli produk diluar lini produk atau jasa.

3. Refers to others. Pelanggan secara teratur menyarankan atau merekomendasikan orang lain untuk mengunakan produk diluar lini produk atau jasa.

4. Immunity. Pelanggan sudah kebal atau tidak lagi tertarik dengan produk pesaing

Maka jelaslah bahwa dengan dilakukan event melalui program event family gathering diharapkan tujuan pemasran dapat tercapai termasuk didalamnya meningkatkan kesadaran atas suatu merek produk, memberikan informasi dan pengetahuan, membengun kepercayaan, memberikan alasan konsumen untuk membeli serta memotivasi konsumen dapat dilaksanakan dengan baik.

Salah satu upaya penciptaan pengenalaan dan peningkatan suatau perusahaan adalah dengan melakukan komunikasi pemasaran. Bentuk komunikasi pemasaran dalam hal ini adalah event 


\section{StrategiC}

melalui program event family gathering. Diharapkan dengan program event family gathering maka dapat mempengaruhi dan meningkatkan kesadaran pelanggan untuk menjadi loyal terhadap perusahaan.

Berdasarkan uraian di atas maka penulis menggambarkan paradigma penelitian sebagai berikut:

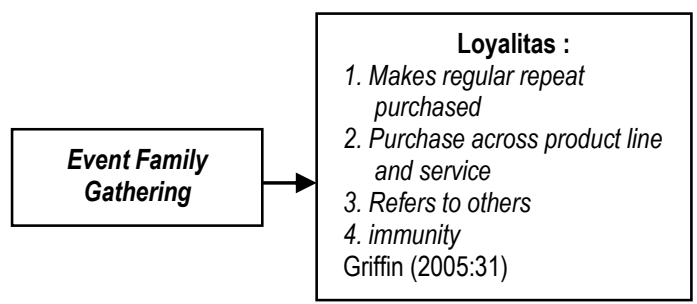

Gambar 3

Paradigma Penelitian

\section{METODE PENELITIAN}

Penelitian ini dilakukan untuk menganalisis menegenai pengaruh program event family gathering terhadap loyalitas pelanggan Hotel Nuansa Bali Anyer. Adapun yang menjadi objek penelitian sebagai variabel bebas $(X)$ atau variabel eksogen adalah program event family gathering. Sedangkan untuk variabel terikat $(\mathrm{Y})$ adalah loyalitas pelanggan yang memiliki empat dimensi yaitu Makes regular repeat purchased, Purchase across product line and service, Refer to other, dan Immunity.

Berdasarkan pertimbangan tujuan penelitian, maka jenis penelitian ini adalah penelitian deskriptif dan penelitian verifikatif. Pengertian penelitian deskriptif dan penelitian verifikatif menurut Suharsimi Arikunto (2007:8).

Penelitian deskriptif adalah penelitian yang bertujuan untuk memperoleh deskriptif tentang ciriciri variabel. Sedangkan sifat penelitian verifikatif pada dasarnya ingin menguji kebenaran suatu hipotesis yang dilaksanakan melalui pengumpulan data dilapangan. Penelitian deskriptif bertujuan untuk memperoleh deskripsi atau gambaran tentang kekuatan event melalui program Family Gathering dan tingkat loyalitas pelanggan perusahaan Hotel Nuansa Bali Anyer, sedangkan penelitian verifikatif bertujuan untuk mengetahui pengaruh event melalui program Family Gathering terhadap loyalitas pelanggan perusahaan Hotel Nuansa Bali Anyer.

Berdasarkan sifat penelitian yaitu deskripsi dan verifikatif, maka metode penelitian yang digunakan adalah metode penelitian populasi atau sensus karena mengambil sampel dari seluruh populasi atau dinamakan sampling jenuh. Sampling jenuh menurut Sugiyono, (2008:122-123).

Sampling jenuh adalah teknik pengumpulan sampel bila semua anggota populasi digunakan sebagai sampel, hal ini sering dilakukan bila jumlah populasi relatif kecil yaitu kurang dari 30 orang, atau penelitian yang ingin membuat generalisasi dengan kesalahan yang sangat kecil. Istilah lainnya adalah sampel jenuh atau sensus, dimana semua anggota populasi dijadikan sampel.

Responden pada penelitian ini adalah pelanggan bisnis jasa Hotel Nuansa Bali Anyer. Penelitian ini dilaksanakan pada kurun waktu kurang dari satu tahun yaitu selama tiga bulan mulai dari November 2008 - Desember 2008, maka metode yang digunakan adalah cross sectional method, yaitu satu jenis rancangan riset yang terdiri dari pengumpulan informasi mengenai sampel tertentu dari elemen populasi hanya satu kali (Malhotra, 2005:95). Berdasarkan variabelvariabel tersebut maka akan diteliti mengenai pengaruh program event family gathering terhadap loyalitas pelanggan.

Tabel 5

Operasionalisasi Variabel Penelitian

\begin{tabular}{|c|c|c|c|c|c|}
\hline Variabel & Sub Vareabel & $\begin{array}{l}\text { Konsep } \\
\text { Variabel }\end{array}$ & Indikator & Ukuran & Skala \\
\hline $\begin{array}{l}\text { Event Family } \\
\text { Gathering } \\
\text { (X) }\end{array}$ & & $\begin{array}{l}\text { Event adalah sebuah } \\
\text { bentuk promosi merek } \\
\text { yang mengikat sebuah } \\
\text { merek dengan aktivitas } \\
\text { publik yang bermakna } \\
\text { dalam bidang kebudayaan, } \\
\text { sosial, atletik, atau jenis } \\
\text { lain yang banyak diminati. } \\
\text { (Shimp, 2003:592) }\end{array}$ & & & \\
\hline
\end{tabular}




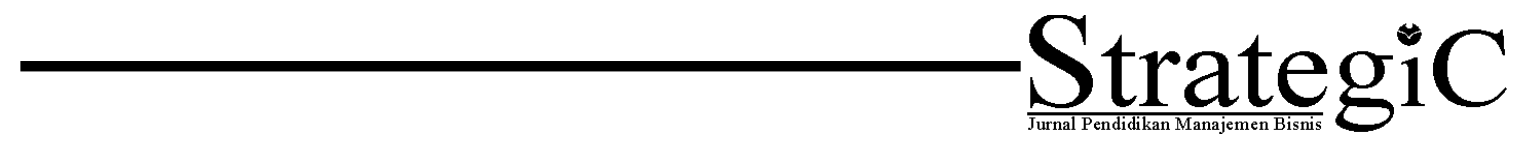

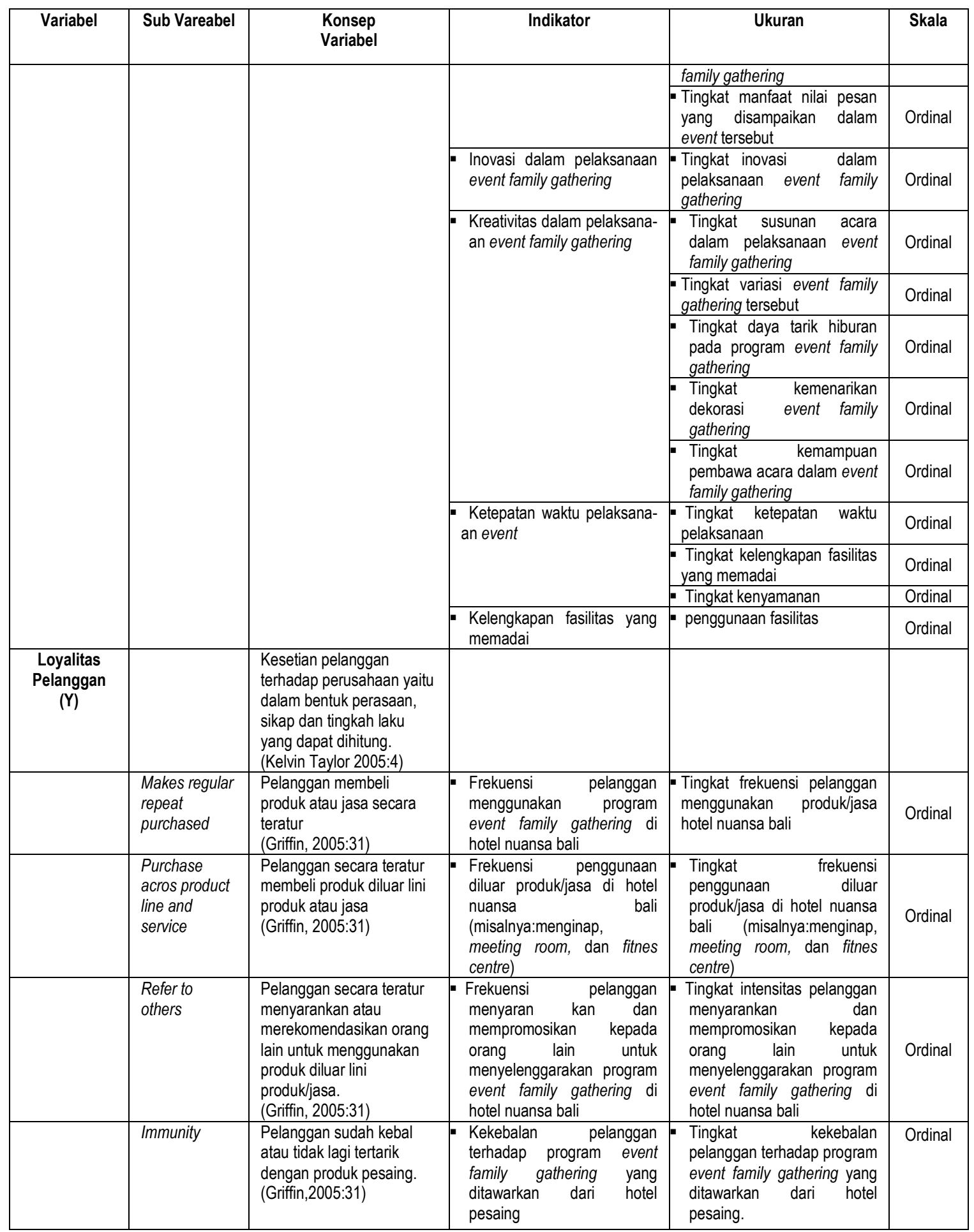

Sumber: Berdasarkan Berbagai Referensi

\section{HASIL PENELITIAN DAN PEMBAHASAN}

Hasil penelitian dan pembahasan akan disajikan secara terurut. Rekapitulasi skor variabel penelitian, pengujian dan pembahasan hipotesis, serta diakhiri dengan penyajian mengenai implikasi penelitian ini terhadap bidang kajian yang diteliti. 


\section{StrategiC}

\section{REKAPITULASI SKOR VARIABEL} PENELITAN

1. Program Event Family Gathering

Penjelasan dari masing-masing indikator program event family gathering dirangkum dalam Tabel 6 yang menyajikan data hasil rekapitulasi skor tanggapan responden mengenai Program event family gathering di Hotel Nuansa Bali. Rekapitulasi skor tersebut menggambarkan perbedaan skor yang diperoleh oleh setiap dimensi dan indikator penelitian.

Tabel 6

Rekapitulasi Skor Tanggapan Responden Mengenai Program Event Family Gathering di Hotel Nuansa Bali

\begin{tabular}{|c|c|c|c|}
\hline No & Dimensi dan Indikator & Skor & Rata-rata \\
\hline \multicolumn{4}{|c|}{ Tema Event Family Gathering } \\
\hline 1. & Daya tarik event family gathering & 77 & \\
\hline \multirow[t]{3}{*}{2.} & Manfaat nilai pesan yang disampaikan dalam event tersebut & 75 & \\
\hline & Sub total & 152 & 76 \\
\hline & Inovasi dalam Pelaksanaan Event Family Gathering & & \\
\hline 1 & $\begin{array}{l}\text { Inovasi propgram pada pelaksanaan event family gathering sehingga } \\
\text { menghasilkan sesuatu yang baru }\end{array}$ & 77 & \\
\hline \multirow[t]{2}{*}{2} & $\begin{array}{l}\text { Inovasi games pada pelaksanaan event family gathering sehingga } \\
\text { menahasilkan sesuatu vana baru }\end{array}$ & 78 & \\
\hline & Sub total & 155 & 77.5 \\
\hline \multicolumn{4}{|c|}{$\begin{array}{l}\text { Kreativitas dalam Pelaksanaan Event Family } \\
\text { Gatherina }\end{array}$} \\
\hline 1. & Susunan acara dalam pelaksanaan event family gathering & 79 & \\
\hline 2. & Variasi event family gathering & 88 & \\
\hline 3. & Daya tarik hiburan event family gathering yang ditampilkan & 78 & \\
\hline 4. & Dekorasi event family gathering & 81 & \\
\hline \multirow[t]{2}{*}{5.} & Kemampuan pembawa acara dalam event family gathering & 84 & \\
\hline & 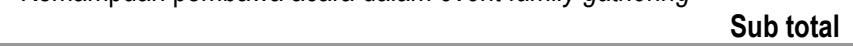 & 410 & 82 \\
\hline & Ketepatan Waktu Pelaksanaan Event & & \\
\hline \multirow[t]{3}{*}{1.} & Ketepatan waktu pelaksanaan event & 77 & \\
\hline & & 77 & 77 \\
\hline & Sub total & & \\
\hline \multicolumn{4}{|c|}{ FasilitasYang Memadai } \\
\hline 1. & Fasilitas yang memadai & 84 & \\
\hline & Kenyamanan penggunaan fasilitas yang diberikan & 84 & \\
\hline & $\begin{array}{l}\text { Sub total } \\
\text { Total }\end{array}$ & $\begin{array}{l}168 \\
962\end{array}$ & 84 \\
\hline
\end{tabular}

Sumber: Hasil Pengolahan Data 2008

Secara keseluruhan variabel program event family gathering dapat diketahui kedudukannya berdasarkan skor yang di dapat berdasarkan data dari Tabel 4.18 di atas, di mana nilai-nilai tersebut dibandingkan dengan kriteria skor standar, yang di dapat melalui perhitungan skor ideal (criterium) dan skor terkecil, sehingga melalui skor standar tersebut dapat diketahui daerah kontinium yang menunjukkan wilayah ideal dari variabel program event family gathering, hal tersebut dapat dicari dengan rumus menurut Sugiono (2006:94) sebagai berikut:

Mencari skor ideal Program Family Gathering

Skor ideal $\longleftrightarrow \begin{aligned} & \text { Skor Tertinggi } x \text { Jumlah Butir Item } x \\ & \text { Jumlah Pengguna }\end{aligned}$
Skor ideal $\longrightarrow 5 \times 12 \times 20=1200$

Mencari skor Terendah Program Family Gathering

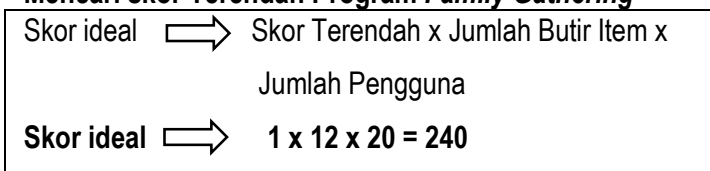

Mencari Panjang Interval Kelas Program Family Gathering

Panjang Interval Kelas $\Longrightarrow$ Skor Ideal : Banyaknya Kelas Interval

Panjang Interval Kelas $\square 1200: 5=240$

Berdasarkan jumlah skor hasil pengumpulan data program event family gathering adalah 962 lihat Tabel 4.18 dengan demikian maka program event family gathering menurut persepsi 20 responden adalah $(962: 1200) \times 100 \%=80.17 \%$. Nilai 962 sesuai dengan data penelitian yaitu 


\section{StrategiC}

termasuk dalam kategori tinggi dan sangat tinggi tetapi lebih mendekati tinggi, jadi program event family gathering dalam kategori tinggi atau baik.

Event adalah salah satu cara efektif untuk menyentuh langsung pasar yang lebih luas. Hal ini dikarenakan event (peristiwa/kejadian) dapat membentuk kegiatan jenis apapun, dapat diselenggarakan dimanapun, dapat dilaksanakan kapanpun, dan dapat berlaku untuk produk apapun. Sedangkan definisi event family gathering menurut Menurut Bartono dan Ruffino (Hotel Communication Management; 2007: 107).

Family gathering merupakan pendekatan hotel pada hubungan primer dengan travel agent dan pemasok, juga mendekatkan hotel dalam hubungan sekunder dengan birokrasi pemerintahan yang berkaitan dengan saluran birokrasi pemerintah yang dapat menguntungkan hotel secara teknis, bisnis dan sosial lingkungan yang tidak hanya melibatkan karyawannya saja tetapi mengikut sertakan keluarganya.

Berdasarkan hasil penelitian yang menggambarkan tanggapan responden terhadap event melalui program event family gathering, maka dapat disimpulkan bahwa hal tersebut sesuai dengan pendapat Shimp (2003:592) menungkapkan bahwa "event adalah sebuah bentuk promosi merek yang mengikat sebuah merek dengan aktivitas publik yang bermakna dalam bidang kebudayaan, sosial, atletik, atau jenis lain yang banyak diminati.

\section{Loyalitas Pelanggan}

Penjelasan dari masing-masing dimensi loyalitas pelanggan dirangkum dalam Tabel rekapitulasi yang tercantum pada Tabel 7 sehingga dapat dilihat perbandingan total skor pada masingmasing dimensi tersebut:

Tabel 7

Rekapitulasi Skor Tanggapan Responden Mengenai Loyalitas Pelanggan

\begin{tabular}{|c|c|c|c|}
\hline No & Dimensi dan Indikator & Skor & Rata-rata \\
\hline \multicolumn{4}{|c|}{ Penggunaan Ulang Produk/Jasa Hotel Nuansa Bali } \\
\hline \multirow[t]{3}{*}{1.} & $\begin{array}{l}\text { Menyelenggarakan kembali program event family gathering di Hotel } \\
\text { Nuansa Bali }\end{array}$ & 86 & \\
\hline & Sub total & 86 & 86 \\
\hline & Penggunaan Produk/Jasa Hotel Lain Yang Sejenis & & \\
\hline \multirow[t]{2}{*}{2} & $\begin{array}{l}\text { Menggunakan produk/jasa diluar event family gathering di Hotel } \\
\text { Nuansa Bali (misalnya: menginap, meeting, fitnes center) }\end{array}$ & 76 & \\
\hline & Sub total & 76 & 76 \\
\hline \multicolumn{4}{|c|}{ Merekomendasikan Kepada Orang Lain } \\
\hline \multirow[t]{3}{*}{3.} & $\begin{array}{l}\text { Mereferensikan/merekomendasikan pihak lain untuk menyelenggarakan } \\
\text { event family gathering di Hotel nuansa Bali. }\end{array}$ & 68 & \\
\hline & Sub total & 68 & 68 \\
\hline & Kekebalan Terhadap Penawaran Hotel Lain & & \\
\hline \multirow[t]{2}{*}{4.} & $\begin{array}{l}\text { Tetap loyal untuk menyelenggarakan program event family gathering di } \\
\text { Hotel Nuansa Bali dan tidak akan beralih kepada hotel pesaing }\end{array}$ & 76 & \\
\hline & $\begin{array}{r}\text { Sub total } \\
\text { Total }\end{array}$ & $\begin{array}{c}76 \\
306\end{array}$ & 76 \\
\hline
\end{tabular}

Sumber: Hasil Pengolahan Data 2008

Mencari skor ideal Loyalitas Pelanggan

Skor ideal $\longleftrightarrow \begin{aligned} & \text { Skor Tertinggi } x \text { Jumlah Butir Item } x \\ & \text { Jumlah Pengguna }\end{aligned}$
Skor ideal $\longleftrightarrow \quad 5 \times 12 \times 20=1200$

Mencari skor Terendah Loyalitas Pelanggan

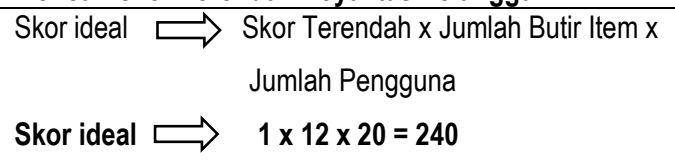

Mencari Panjang Interval Kelas Loyalitas Pelanggan

\begin{tabular}{|l} 
Panjang Interval Kelas $\longrightarrow \begin{array}{l}\text { Skor Ideal : Banyaknya } \\
\text { Kelas Interval }\end{array}$ \\
Panjang Interval Kelas $\longrightarrow 1200: 5=240$ \\
\hline
\end{tabular}

Berdasarkan Tabel 7 dibandingkan dengan skor ideal penggunaan ulang produk/jasa Hotel Nuansa Bali memperoleh skor tertinggi sebesar 86 termasuk dalam kategori kuat. Sedangkan jumlah skor terendah adalah tetap loyal terhadap Hotel Nuansa Bali dan tidak akan beralih ke hotel lain yaitu sebesar 68 termasuk dalam kategori sedang. Nilai 306 sesuai dengan data penelitian yaitu 
termasuk dalam kategori sedang dan tinggi tetapi lebih mendekati tinggi, jadi program event family gathering dalam kategori tinggi atau baik.

Loyalitas pelanggan merupakan komitmen untuk bertahan secara mendalam untuk melakukan pembelian ulang atau berlangganan kembali produk atau jasa terpilih secara konsisten untuk meyebabkan perubahan perilaku. Sedangkan definisi loyalitas menurut Griffin (2005:5), lebih mengarah kepada perilaku dibandingkan dengan sikap dan seorang pelanggan yang loyal akan memperlihatkan perilaku pembelian yang dapat diartikan sebagai pola pembelian yang teratur dan dalam waktu yang lama, yang dibuat oleh unit-unit pembuat atau pengambil keputusan.

Pelanggan yang loyal merupakan aset penting bagi perusahaan, hal ini dapat dilihat dari karakteristik yang dimilikinya, sebagaimana diungkapkan oleh Griffin (2008:105), pelanggan yang loyal memiliki karakteristik sebagai berikut:

1. Melakukan pembelian secara teratur (Makes regular repeat purchases)

2. Membeli diluar lini produk/jasa (Purchase across product and service line)

3. Merekomendasikan produk kepada orang lain (Refers to others)

4. Menunjukkan kekebalan dari daya tarik produk sejenis dari pesaing (Demonstrates an immunity to the full of the competition)

Berdasarkan hasil penyebaran terhadap 20 responden pelanggan bisnis Hotel Nuansa Bali Anyer dapat diketahui pula gambaran loyalitas pelanggan Hotel Nuansa Bali melalui beberapa tahapan menurut Griffin (2008:35) mulai dari Customer, Client, advocates sampai Partner. Adapun perhitungannya sebagai berikut:

1. Skor tertinggi yang diperoleh dari hasil jawaban responden dalam dimensi loyalitas pelanggan Hotel Nuansa Bali yaitu 20, sedangkan skor terendah yang diperoleh yaitu sebesar 10 .

2. Setelah mengetahui skor tertinggi dan terendah dapat ditentukan batas atas dan batas bawah, yaitu batas atasnya sebesar 20,5 dan batas bawahnya sebesar 9,5 .

3. Diketahui rentang antara batas atas dan batas bawah kelas interval adalah 10 (hasil pengurangan batas atas dan batas bawah) kemudian rentang kelas tersebut dibagi ke dalam 4 kelompok tahapan loyalitas penumpang, yaitu Customer, Client, Advocates sampai Partner karena yang dijadikan populasi dalam penelitian ini adalah 20 perusahaan yang mengukuti program event family gathering di Hotel Nuansa Bali.

4. Berdasarkan hasil perhitungan tersebut dapat disajikan ke dalam tabel 8 berikut ini.

Tabel 8

Perhitungan Gambaran Loyalitas Pelanggan Bisnis Hotel Nuansa Bali Anyer

\begin{tabular}{|l|l|l|l|l|l|}
\hline No & $\begin{array}{c}\text { Tingkatan } \\
\text { Loyalitas }\end{array}$ & $\begin{array}{c}\text { Skala } \\
\text { Interval }\end{array}$ & Fre. & $\begin{array}{c}\text { Fre. } \\
\text { Kumulatif }\end{array}$ & \multicolumn{1}{|c|}{ Persentase } \\
\hline 1 & Partner & $18,5-21,5$ & 3 & 3 & $\begin{array}{l}3 / 20 \times 100 \%= \\
15 \%\end{array}$ \\
\hline 2 & Advocates & $15,5-18,5$ & 7 & 10 & $\begin{array}{l}10 / 20 \times 100 \% \\
=50 \%\end{array}$ \\
\hline 3 & Client & $12,5-15,5$ & 4 & 14 & $\begin{array}{l}14 / 20 \times 100 \% \\
=70 \%\end{array}$ \\
\hline 4 & Customer & $9,5-12,5$ & 6 & 20 & $\begin{array}{l}20 / 20 \times 100 \% \\
=100 \%\end{array}$ \\
\hline
\end{tabular}

Berdasarkan Tabel 8 di atas, terlihat bahwa penumpang pada tahap Customer sebanyak $100 \%$, artinya keseluruhan responden dianggap telah pernah mengadakan program event family gathering di Hotel Nuansa Bali Anyer namun dalam tahap ini loyalitas belum terlihat. Tahapan selanjutnya adalah Clients sebanyak $70 \%$, pada tahap ini pelanggan telah mengadakan program event family gathering di Hotel Nuansa Bali secara teratur. Tahapan Advocate sebanyak $50 \%$, pada tahap ini pelanggan secara aktif mendukung perusahaan dengan memberikan rekomendasi kepada orang lain agar mengadakan program event family gathering di Hotel Nuansa Bali. Untuk tahapan Partner sebanyak 15\%, pada tahap ini telah terjadi hubungan yang kuat dan saling menguntungkan antara pelanggan dan pihak Hotel Nuansa Bali karena pada tahap ini pelanggan berani menolak produk dari perusahaan lain.

\section{HASIL PENGUJIAN DAN PEMBAHASAN HIPOTESIS}

Hipotesis yang akan di uji dalam penelitian ini adalah pengaruh program event family gathering terhadap loyalitas pelanggan Hotel Nuansa Bali Anyer. Pengujian pengaruh antar variabel ini menggunakan aplikasi software SPSS for window 15

\section{Besar Korelasi Antar Variabel Penelitian}

Berdasarkan out put SPSS di atas dapat diketahui bahwa nilai koefisien determinasi ( $R$ square) sebesar 0,660 . Hal ini menunjukkan bahwa tingkat korelasi atau hubungan antara program event family gathering dengan loyalitas pelanggan Hotel Nuansa Bali sebesar 0,660 (66 
$\%$ ), yang berarti bahwa $66 \%$ variabel loyalitas pelanggan dijelaskan oleh program event family gathering, dan sisanya $34 \% \quad(100 \%-66 \%)$ dijelaskan oleh variabel lain di luar variabel yang diteliti. Termasuk ke dalam kategori sedang.

Tabel 9

Output Nilai Pengaruh Antara Variabel Penelitian Model Summary(b)

\begin{tabular}{|c|c|c|c|c|}
\hline Model & $\mathrm{R}$ & R Square & $\begin{array}{l}\text { Adjuste } \\
\text { d R } \\
\text { Square }\end{array}$ & $\begin{array}{l}\text { Std. Error of } \\
\text { the Estimate }\end{array}$ \\
\hline 1 & ,813(a) & 660 & ,642 & 1,87175 \\
\hline
\end{tabular}

a Predictors: (Constant), $X$

b Dependent Variable: $Y$

2. Analisis Regresi Linear Sederhana Tabel 10

Output Koefisien Regresi Coefficients(a)

\begin{tabular}{|c|c|c|c|c|c|}
\hline \multirow[b]{2}{*}{ Model } & \multicolumn{2}{|c|}{$\begin{array}{l}\text { Unstandardized } \\
\text { Coefficients }\end{array}$} & \multirow{2}{*}{$\begin{array}{c}\text { Standardize } \\
d \\
\text { Coefficients } \\
\text { Beta }\end{array}$} & \multirow{2}{*}{$\mathrm{t}$} & \multirow{2}{*}{$\begin{array}{l}\text { Sig. } \\
\text { Std. } \\
\text { Error }\end{array}$} \\
\hline & B & $\begin{array}{l}\text { Std. } \\
\text { Error }\end{array}$ & & & \\
\hline $\begin{array}{l}1 \text { (Constant) } \\
\mathrm{X}\end{array}$ & $\begin{array}{r}2,474 \\
, 309\end{array}$ & $\begin{array}{r}1,482 \\
, 052 \\
\end{array}$ & 813 & $\begin{array}{l}1,669 \\
5,916\end{array}$ & $\begin{array}{l}, 112 \\
, 000\end{array}$ \\
\hline
\end{tabular}

a Dependent Variable: Loyalitas Pelanggan

Berdasarkan pengolahan data secara regresi liner sederhana dengan menggunakan program SPSS for windows 15, maka diperoleh persamaan regresi linear sederhana antara event family gathering dan loyalitas pelanggan, yaitu:

Loyalitas Pelanggan $=2,474+0,309$ Event Family Gathering

Berdasarkan persamaan regresi di atas, konstanta sebesar 2,474 menyatakan bahwa jika tidak ada event family gathering atau $X$ konstan $(X$ $=0$ ) maka besarnya nilai loyalitas pelanggan adalah 2,474. Tetapi jika terdapat perubahan sebesar 1000 pada variabel event family gathering maka nilai variabel loyalitas pelanggan akan mengalami penambahan sebesar 0,309

$(0,309 \times 1000)$. Adapun bentuk dari garis linear Program Event Family Gatheing terhadap Loyalitas Pelanggan dapat dilihat pada Gambar 4:

Gambar tersebut menunjukan bahwa data menyebar disekitar garis diagonal dan mengikuti arah diagonal. Maka, model regresi memenuhi asumsi normalitas.

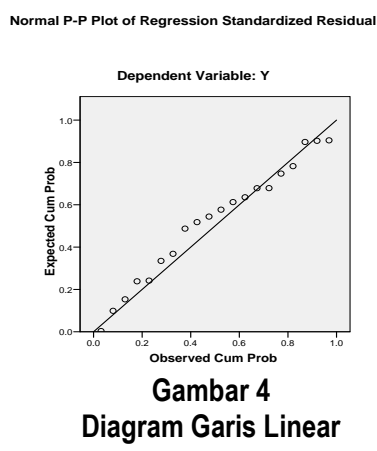

\section{Koefisien Determenasi}

Untuk mengetahui besarnya pengaruh variabel $X$ terhadap $Y$, maka digunakan rumus koefisien determinasi sebagai berikut :

$$
\begin{aligned}
\mathrm{KD} & =\mathrm{r}^{2} \times 100 \% \\
& =(0.813)^{2} \times 100 \% \\
& =66,1 \%
\end{aligned}
$$

Hasil perhitungan di atas menunjukan bahwa besarnya koefisien determinasi adalah $66,1 \%$. Hal ini berarti bahwa $66,1 \%$ loyalitas pelanggan Hotel Nuansa Bali dipengaruhi oleh program event family gathering, dan sisisanya 33,9\% loyalitas pelanggan Hotel Nuansa Bali dipengaruhi oleh variabel lain diluar variabel yang diteliti.

Hipotesis yang diuji yaitu pengaruh program event family gathering $(X)$ terhadap loyalitas pelanggan (Y). Untuk menguji signifikansi konstanta dari variabel $X$ diperoleh dari uji $t$ dengan hipotesis sebagai berikut:

$H_{o}: \rho \leq 0$,

Artinya tidak terdapat pengaruh yang positif dan signifikan program event family gathering terhadap loyalitas pelanggan Hotel Nuansa Bali Anyer.

$H_{1}: \rho>0$,

Artinya terdapat pengaruh yang positif dan signifikan program event family gathering terhadap loyalitas pelanggan Hotel Nuansa Bali Anyer.

Pengujian signifikansi dapat dilakukan dengan membandingkan nilai $t_{\text {tabel }}$ dengan harga $t_{\text {hitung, }}$ untuk taraf kesalahan $5 \%$ uji satu pihak dengan $\mathrm{dk}$ $=\mathrm{n}-2$, dengan menggunakan aplikasi software SPSS 15 maka diperoleh $t_{\text {hitung }}$ sebesar $=5,916$.

Berdasarkan hasil perhitungan, maka diperoleh $t_{\text {titung }}$ sebesar $=5,916$; sedangkan dalam tabel pada taraf signifikansi $=0,05$ dengan derajat kebebasan (dk) $\mathrm{N}-2=20-2=18$, terdapat dalam tabel 


\section{StrategiC}

sebesar tabel 1,743 . Dengan demikian, maka $t_{\text {hitung }}$ $=5,916>\mathrm{t}$ tabel $=1,743$ artinya hipotesis nol $\left(\mathrm{H}_{0}\right)$ ditolak, dengan kata lain hipotesis yang diajukan penulis diterima yaitu: loyalitas pelanggan dipengaruhi secara positif oleh program event family gathering.

Adapun rangkuman hasil pengujian hipotesis dapat dilihat pada Tabel 11 berikut ini.

Tabel 11

Rangkuman Hasil Uji Hipotesis

\begin{tabular}{|l|c|c|l|}
\hline \multicolumn{1}{|c|}{ Hipotesis } & thitung & $\mathbf{t}_{\text {tabel }}$ & \multicolumn{1}{|c|}{ Keputusan } \\
\hline $\begin{array}{l}\text { Terdapat pengaruh prog- } \\
\text { ram event family gathering } \\
\text { terhadap loyalitas pelang- } \\
\text { gan }\end{array}$ & 5,916 & 1,743 & $\begin{array}{l}\text { Ho ditolak, dan } \\
\text { Ha diterima }\end{array}$ \\
\hline
\end{tabular}

Sumber : Hasil Pengolahan Data 2008

Berdasarkan hasil analisis data, maka diperoleh kesimpulan bahwa event family gathering mempunyai hubungan dengan loyalitas pelanggan, dimana nilai korelasi ( $r$ ) adalah sebesar 0,813. Hal ini berarti bahwa antara event family gathering dengan loyalitas pelanggan yang akan dibentuk mempunyai korelasi dalam kategori kuat. Hal ini terbukti dengan hasil perhitungan koefisien determinasi yaitu dengan menguadratkan koefisien korelasi $r^{2} X 100 \%=(0,813)^{2} X 100 \%$ diperoleh hasil sebesar $66,1 \%$ yang berarti bahwa perubahan variabel loyalitas pelanggan sebesar $66,1 \%$ dipengaruhi oleh event family gathering. Sedangkan 33,9\% loyalitas pelanggan dipengaruhi oleh faktor lain. Pengambilan keputusan pengujian hipotesis dilakukan dengan membandingkan thitung dengan tabel perhitungan uji signifikansi dengan menggunakan alpha 0,05 pada uji satu pihak dengan derajat kebebasan (dk)n-2 maka dk=18 diperoleh thitung dan tabel dengan taraf kesalahan $5 \%$. Berdasarkan ketentuan hipotesis diterima jika thitung $>t_{\text {tabel }}$ maka diketahui bahwa harga thitung $>t_{\text {tabel }}(5,916>1,743)$ sehingga dapat disimpulkan bahwa koefisien korelasi antara variabel event family gathering dengan loyalitas pelanggan memiliki hubungan yang signifikan.

Pernyataan tersebut diperoleh melalui pengujian hipotesis yang menggunakan metode regresi linier sederhana, regresi tersebut ditunjukkan dengan perolehan loyalitas pelanggan sebesar 2,474 dimana hasil tersebut dapat diartikan bila nilai setiap penambahan $1 \%$ event family gathering akan meningkatkan loyalitas pelanggan yaitu sebesar 2,474 ditambah 0,309 dari program event family gathering $(Y=2,474+$
$0,309 X)$, dimana koefisien determinasi $\left(r^{2}\right)$ yaitu 0,66 termasuk kategori tinggi berada diantara $(0,60-0,79)$.

Koefisien korelasi yang bernilai positif menunjukan bahwa hubungan antara kedua variabel tersebut berbanding lurus, artinya jika perusahaan meningkatkan event family gathering di mata pelanggan maka dapat diprediksi bahwa loyalitas pelanggan akan naik. Namun, sebaliknya jika perusahaan tidak meningkatkan event family gatheringnya maka loyalitas pelanggan bisa menurun.

\section{IMPLIKASI PENELITIAN}

Berdasarkan hasil pengolahan data untuk variabel pengaruh event melalui program event family gathering terhadap loyalitas pelanggan menghasilkan penolakan $\mathrm{Ho}$, artinya dapat dinyatakan bahwa terdapat pengaruh yang positif dan signifikan antara event family gathering terhadap loyalitas pelanggan Hotel Nuansa Bali Anyer, persentase ideal adalah 100\% namun dalam penelitian ini persentase pengaruh event melalui program event family gathering terhadap loyalitas pelanggan adalah sebesar $66,1 \%$ karena sisanya sebesar $33,9 \%$ merupakan pengaruh dari faktor lain yang tidak termasuk dalam penelitian ini.

Indikator dari program event family gathering yang paling mempengaruhi loyalitas pelanggan adalah fasilitas dalam pelaksanaan event, karena sebagian besar responden menyatakan bahwa program event family gathering yang dijalankan Hotel Nuansa Bali telah sesuai dengan kebutuhan dan keinginan pelanggan. Hal ini sebagai langkah pertama dalam program event family gathering kegiatan tersebut dapat diminati, selanjutnya bagaiman pihak Hotel Nuansa Bali menyesuaikan produk yang akan dijual dengan kebutuhan dalam program tersebut.

Kreativitas dalam program event family gathering meningkatkan loyalitas pelanggan, karena kreativitas merupakan tujuan utama hendak dicapainya suatu kegiatan. Hotel Nuansa Bali dalam menjalankan kreativitasnya menekankan pada panitia acaranya agar dapat membuat kreativitas semenrik mungkin untuk para pelanggan yang mengikuti event family gathering agar menimbulkan keyakinan untuk menggunakan ulang produk/jasa dari Hotel Nuansa Bali.

Inovasi dalam program event family gathering mempengaruhi untuk peningkatan terhadap 
loyalitas pelanggan, karena dengan adanya inovasi-inovasi dalam suatu event membuat perubahan yang yang lebih baik dan menarik maka menimbulkan rasa penasaran pelanggan untuk kembali mengadakan event family gathering kembali di Hotel Nuansa Bali.

Ketepatan waktu dalam pelaksanaan program event family gathering meningkatkan loyalitas pelanggan, karena dengan adanya ketepatan waktu pelaksanaan membuat pelanggan merasa puas sehingga membuat pelanggan untuk kembali mengadakan program event family gathering di Hotel Nuansa Bali.

Tema dalam pelaksanaan program event family gathering untuk meningkatkan loyalitas pelanggan merupakan tujuan untuk menarik para pelanggan untuk mengadakan kembali program event family gathering di Hotel Nuansa Bali.

Berdasarkan hal di atas, bahwa nilai penaguruh event melalui program event family gathering terhadap loyalitas pelanggan Hotel Nuansa Bali Anyer tergolong kuat. Hotel Nuansa Bali harus mengimplementasikan program tersebut agar masalah loyalitas segera teratasi.

Hal tersebut sesuai dengan pendapat yang disampaikan oleh Soemanagara (2006:63), bahwa event yang merupakan bagian dari komunikasi pemasaran memiliki tujuan akhir untuk menciptakan loyalitas. Komunikasi pemasaran bertujuan untuk mencapai tiga tahap perubahan yang ditujukan kepada konsumen. Tahap pertama adalah perubahan pengetahuan (knowledge), dalam perubahan ini konsumen mengetahui keberadaan sebuah produk, untuk apa produk itu diciptakan (aware). Tahan ke dua perubahan sikap, yaitu memunculkan rasa perhatian (interest), perubahan ini mengarah kepada keinginan untuk mencoba (trial) produk, semakin tinggi kesukaan konsumen terhadap suatu pesan sponsor semakin besar kemungkinan konsumen membeli produk tersebut. Tahap ke tiga adalah perubahan prilaku yaitu membentuk loyalitas (loyalty).

Event sebagai bentuk promosi yang merupakan komunikasi pemasaran memiliki tujuan akhir untuk membentuk loyalitas pelanggan, disampaikan dalam pengertian promosi menurut Buchari Alma (2005:179), Promosi merupakan komunikasi pemasaran yang bertujuan menyebarkan informasi, mempengaruhi atau membujuk, dan atau mengingatkan pasar sasaran atas produknya melalui rangkian aktivitas agar konsumen bersedia menerima, membeli, dan loyal pada produk yang ditawarkan perusahaan bersangkutan.

\section{SIMPULAN DAN SARAN}

\section{Simpulan}

Berdasarkan uraian teori, pengolahan data dan pembahasan pada bab sebelumnya, maka dapat disimpulkan bahwa:

1. Tanggapan responden terhadap program event family gathering secara umum sudah baik, persepsi responden terhadap variasi event family gathering, merupakan indikator yang paling tinggi mendapatkan skor. Variasi event family gathering tersebut dianggap sangat menarik oleh pelanggan karena variasi dalam susunan acara dan penggunaan metode pendekatan luar ruangan yang digunakan dalam penyelenggaraan acara dirancang sedemikian rupa, sehingga menjadi menarik, menantang, dan tidak membosankan bagi peserta pada program event family gathering di Hotel Nuansa Bali Anyer. Sedangkan perolehan hasil pada indikator manfaat nilai pesan yang disampaikan dalam event family gathering mendapatkan skor yang paling rendah dari indikator-indikator lainnya, hal ini dikarenakan perusahaan tidak terlalu memperhatikan keseuaian antara tema dengan manfaat yang akan disampaikan pada program event family gathering di Hotel Nuansa Bali.

2. Tanggapan responden terhadap loyalitas pelanggan yang terdiri dari penggunaan program event family gathering secara teratur, penggunaan diluar program event family gathering,, merekomendasikan produk/jasa kepada orang lain, menunjukan kekebalan terhadap penawaran program event family gathering dari hotel lain secara umum sudah baik. Persepsi responden terhadap penggunaan ulang program event family gathering merupakan dimensi yang memperoleh skor yang paling tinggi hal ini dikarenakan program event family gathering yang dilakukan di Hotel Nuansa Bali memberikan kepuasan dari segi fasilitas, permainanya, makananya, dan lain sebagainya. Sedangkan persepsi responden merekomendasikan kepada orang lain, mendapatkan skor yang paling rendah dari dimensi-dimensi lainnya, hal ini dikarenakan 


\section{StrategiC}

memang perusahaan tidak memberikan pendekatan-pendekatan kepada pelanggan untuk merekomendasikan program event family gathering di Hotel Nuansa Bali kepada orang lain.

3. Program event family gathering berpengaruh secara positif terhadap loyalitas pelanggan. Sehingga program acara yang berkualitas, inovatif dan berbeda dengan perusahaan lain yang baik di masyarakat akan memberikan pengaruh yang positif terhadap loyalitas pelanggan.

Secara keseluruhan berdasarkan hasil pengolahan data menunjukan pada umumnya program event family gathering yang terdiri dari daya tarik tema, manfaat nilai pesan, inovasi, kreativitas, ketepatan waktu, dan fasilitas berpengaruh positif terhadap loyalitas pelanggan Hotel Nuansa Bali Anyer.

\section{Saran}

Saran penulis untuk meningkatkan loyalitas pelanggan Hotel Nuansa Bali, maka perusahaan harus mempertahankan hasil-hasil positif yang telah dicapai dan meningkatkan kualitas yang lebih baik, yang selama ini telah dilaksanakan. Berdasarkan hasil penelitian, maka penulis merekomendasikan hal-hal berikut:

1. Program event family gathering merupakan salah satu strategi yang penting dalam meningkatkan loyalitas pelanggan Hotel Nuansa Bali, namun hal terpenting yang harus diperhatikan oleh pihak Hotel adalah program acara harus memiliki keunikan yang sulit ditiru pesaing. Agar sulit ditiru pesaing, program event family gathering harus tersusun dari beragam kreativitas yang cukup banyak dan menarik. Berdasarkan hasil penelitian diketahui bahwa pada indikator mengenai manfaat nilai pesan yang memiliki tanggapan paling rendah karena itu sebagai solusi diharapkan perusahaan dapat lebih kreativ dalam memberikan nilai pesan kepada pelanggan sehingga manfaat yang disampaikan sangat berguna dan berkesan bagi pelanggan, dan perusahaan atau pihak hotel harus bisa menilai keinginan pelanggan.

2. Persepsi masyarakat terhadap loyalitas pelanggan sudah cukup baik, namun untuk mempertahankan agar selalu meningkat dalam jangka waktu yang lama atau berkesinambungan dapat dilakukan melalui strategi pendekatan terhadap pelanggan dengan memberikan potongan harga, membuat games-games baru yang tidak monoton agar tidak membosankan pelanggan, fasilisator dalam acara harus lebih memiliki kreativitas yang lebih kreativ. Berdasarkan hasil penelitian diketahui bahwa pada dimensi merekomendasikan kepada pihak lain memperoleh nilai terendah, oleh karena itu pihak hotel harus bisa mendekatkan kepada pelanggan unuk merekomendasikan program event family gathering kepada pihak lain dengan cara memberi hadiah-hadiah yang menarik.

3. Berdasarkan penelitian bahwa program event family gathering memberikan pengaruh yang positif terhadap loyalitas pelanggan akan tetapi Hotel Nuansa Bali harus memperhatikan kebutuhan dan keinginan pelanggan serta memberikan manfaat bagi pelanggannya, dengan demikian pelanggan akan memperhatikan makna dari strategi sehingga akan membentuk nilai yang positif dalam benak pelanggan dan pada akhirnya akan tercipta loyalitas pelanggan yang kuat.

\section{DAFTAR PUSTAKA}

Any Noor. 2007. Globalisasi Industri MICE. Bandung: CV. Alfabeta.

Asep Hermawan. 2006. Penelitian Bisnis Paradigma Kuantitatif. Jakarta: Grasindo

Bagyono, 2007. Pariwisata dan Perhotelan. Bandung: Alfabeta.

Bartono, Ruffino. 2007. Hotel Communication Management. Yogyakarta: ANDI.

Buchari Alma. 2004. Manajemen Pemasaran dan Pemasaran Jasa. Bandung: CV. Alfabeta.

Fandy Tjiptono. 2002. Strategi Pemasaran. Yogyakarta: ANDI.

Fandy Tjiptono. 2005. Brand Management and Strategy. Yogyakarta: ANDI.

Fandy Tjiptono. 2006. Pemasaran Jasa. Malang: Bayu Media Publishing.

Freddy Rangkuti. 2002. Measuring Customer Satisfaction. Jakarta: Gramedia Pustaka Utama

Griffin. Jill. 2005. Customer Loyality Menumbuhkan dan Mempertahankan Kesetian Pelanggan. Jakarta: Erlangga

Harun Al Rasyid Harun. 1994. Teknik Penarikan Sample dan Pengukuran Skala. Bandung: Pasca Sarjana UNPAD. 
Hermawan Kartajaya. 2007. Bosting Loyality Marketing Performance. Jakarta: Mizan dan MarkPlus\&Co,

Indriantoro dan Supomo. 2002. Metodologi Penelitian Bisnis. Yogyakarta: BPFE

Kartajaya Hermawan, Yus Wohady, Madyani, D, Indrio, B.D.. 2003. Marketing in Venus. Jakarta: PT Gramedia Pustaka Utama.

Kotler dan Amstrong. 2006. Prinsip-Prinsip Pemasaran, Jakarta: PT Indeks

Kotler, Keller. 2007. Manajemen Pemasaran. Jakarta: PT. Indeks Kelompok Gramedia

Kotler, Philip, dan Kevin Keller. 2006. Marketing Management $12^{\text {th }}$ Edition. New Jersey: Prentice Hall - Pearson International

Kotler, Philip. 2005. Manajemen Pemasaran. Jilid 1\&2. Jakarta: Prenticehall

Leonard H. Hoyler, Jr. 2006. Event Marketing. Jakarta: PPM.

Lovelock, Christopher, Jochen Wirtz, Hean Tat Keh, Xiongwan Lu. 2005. Service Marketing in Asia: Managing People, Technology, and Strategy. Second Edition. New Jersey: Pearson - Prentice Hall

Lovelock, Christopher. 2007. Manajemen Pemasaran Jasa. Jakarta: Indeks

Malhotra, Naresh K.. 2005. Riset Pemasaran. Jakarta: Indeks Kelompok Gramedia

Nigel Hill. 1996. Hand Book of Customer Satisfaction Measurement. England: Gowr Publising Ltd

Oliver, Richard I.. 1997. Satisfaction a Behavioural Perspective on The Customer. Toronto Vanderbilt University: The Mc Grow Hill Companies, Inc

Rambat Lupiyoadi dan Hamdani. A.. 2006. Manajemen Pemasaran Jasa. Jakarta: Salemba Empat.

Ratih Hurriyati. 2005. Bauran Pemasaran dan Loyalitas Pelanggan. Jakarta: Alfabeta

Shimp, Terence A.. 1993. Advertising Promotion, South Carolina: The Dryden Press

Shimp, Terence A.. 1993. Promotion Event. South Carolina : The Dryden Press.

Soemanagara. 2006. Strategic Marketing Communication Konsep Strategis dan terapan. Bandung: CV. Alfabeta

Sudjana. 2000. Metoda Statistika. Bandung: Tarsito

Sudjana. 2001. Teknik Analisa Regresi dan Korelasi. Bandung: Tarsito

Sugiyono. 2005. Statistika untuk Penelitian. Bandung: CV. Alfabeta.
Sugiyono. 2008. Metode Penelitian Bisnis. Bandung: CV. Alfabeta

Suharsimi Arikunto. 2007. Prosedur Penelitian: Suatu Pendekatan Praktek. Jakarta: Rineka Cipta.

Umar, Husein. 2002. Metode Penelitian Bisnis. Jakarta: PT Gramedia Pustaka Utama.

Vanessa Gaffar, 2007. CRM dan MPR Hotel (Customer Relationship Management and Marketing Public Relations). Bandung: CV. Alfabeta

Yazid. 2005. Pemasaran Jasa. Yogyakarta: Ekonisia

Zeithaml, Valerie A. \& Mary Jo Bitner. 2006. Service Marketing Integrating Customer Focus Across The Firm. New Jersey: Prentice Hall International, Inc.

Zikmund, William G. 2003. Exploring Marketing Research 8th Edition. USA, South Western: A Division of Thomson Learning, Ohio

\footnotetext{
Pengaruh Program Event Family Gathering terhadap Loyalitas Pelanggan Bisnis pada Hotel Nuansa Bali Anyer
} 